\title{
The Impact of Complaints between Frontline Service Employees on Consumers-Based on Critical Incident Technique
}

\author{
Jihua Zhang, Ningning Wang \\ School of Management, Jinan University, Guangzhou, China \\ Email: wangnn500@163.com
}

How to cite this paper: Zhang, J.H. and Wang, N.N. (2018) The Impact of Complaints between Frontline Service Employees on Consumers-Based on Critical Incident Technique. American Journal of Industrial and Business Management, $\mathbf{8}$, 793-802.

https://doi.org/10.4236/ajibm.2018.83054

Received: March 2, 2018

Accepted: March 27, 2018

Published: March 30, 2018

Copyright $\odot 2018$ by authors and Scientific Research Publishing Inc. This work is licensed under the Creative Commons Attribution International License (CC BY 4.0).

http://creativecommons.org/licenses/by/4.0/

\begin{abstract}
The critical incident technique was adopted to collect 174 critical events which were divided into 3 categories and 9 types about the complaint behaviors among the front-line service employees witnessed by the consumers. In addition, this paper discusses the influence mechanism of employees' complaint behavior on consumers and enriches the theory research of employees' complaints and brand internalization.
\end{abstract}

\section{Keywords}

Employees Complain, Service Encounter, Critical Incident Technique

\section{Introduction}

The employees often have many grievances and dissatisfaction because of the reason of work or interpersonal relationship, and complain about these grievances in the workplace or in private. For example, employees complain about low pay, unreasonable enterprise rules and regulations, etc. (Gao 2014) [1].

The current research on employee complaints is concentrated in the field of human resources, including the impact of employee complaints on employee enthusiasm (Godard 2014) [2], employee voice (Mowbray et al. 2015) [3], turnover intention (Watty-Benjamin and Udechukwu, 2014) [4] and so on. Only a few discussions have been made on the influence of the employee's complaints on customers.

However, for the front-line service staff who work between an enterprise and its customers, providing products or services to consumers, there is a lot of contact and interaction with consumers (Surprenant and Solomon 1987) [5]. If front-line service employees complain to each other in the workplace, consum- 
ers will be able to witness this kind of complaining behavior. Employee behavior, especially the behavior of front-line service employee, plays an important role in brand building (Tavassoli et al., 2014) [6], which influences the formation of brand personality (Wentzel 2009) [7]. Scholars call it brand advocates. In this way, it seems that the behavior of complaint between the frontline service employees witnessed by consumer is contrary to the effort to create the brand through employees (Asha and Jyothi, 2013; Sivakumar et al., 2014) [8] [9]. The resulting management problems: Whether, when, and why witnessing employee complaint behavior affects consumers.

The paper attempts to use the critical incident technique to make exploratory analysis on the complaining behavior among the front-line service employee that are seen and heard by customers in order to enrich the theory research of employees' complaints and brand internalization, and provide advice for managers to manage front-line service employee.

\section{Literature Review}

\section{Complaints between front-line service employees}

According to the involved stakeholders (Mcwilliams and Siegel 2002) [10], the types of complaints among employees can be divided into three aspects: a) Complaints triggered by the corporate employee responsibility. Employees think that the company's responsibilities for employees' remuneration, physical and mental health, career planning and development, and work environment are not well. b) Complaints triggered by the corporate consumer responsibility. In order to improve efficiency, reduce costs, improve service quality, and please consumers, the company puts forward strict requirements on employees' work ability, work intensity and attitude, resulting in complaints from employees. c) Complaints triggered by employee personal relationships (Zhang et al. 2012) [11]. Dissatisfaction with personal relationships between employees and other colleagues, resulting in complaints. In addition, for first-line service employees working directly in the enterprise-consumer interface and providing services directly to consumers (Hartline and Ferrell 1996) [12], complaints about job content may also be complaints from consumers. Now the types of employee complaints are summarized based on the employee's perspectives, the consumer's perspectives are not clear. So the critical incident technique was adopted to summarize the complaints among front-line service employees witnessed by consumer perspectives.

\section{Service encounter}

Surprenant and Solomon (1987) proposed that service encounter is the interaction between customers and service providers [5]. First-line service employees must have a lot of service encounter and interaction with consumers in the process of providing products or services to consumers. Moreover, the object of service encounter is not limited to the interaction between the consumer and the service provider, but also includes all other elements (Bitner 1992) [13]. So if front-line service employees complain in the workplace, even the front-line ser- 
vice employees with complaints do not interact with consumers, consumers can also see and hear such complaints.

\section{Influence mechanism of employees' complaint behavior on consumers}

Consumer perception and trust in the brand often comes from employee behavior (Qiu and Bai 2012) [14]. During the service process, Relative to "hardware" factors such as environment and facilities, the contact between front-line service employees and consumers has a more important impact on the perception of service quality (Bitner 1992) [13]. But there have been no scholars specific to the impact of employee complaints on consumers. After combing, we conclude that the following two mechanisms may cause the complaints among front-line service employees to affect consumers: emotional infection, service encounter evaluation model.

\section{Emotional infection}

Positive emotions of service personnel affect the positive mood changes of consumers. However, in the actual service consumption, the service provider's negative emotional information is often more easily captured and absorbed by the consumer, which in turn affects the negative emotional changes (Hennigthurau 2001) [15]. So in the service encounter, employee complaining behavior as a negative emotional expression can cause emotional infection between employees and consumers. And the feelings of the employees will affect their evaluation of service and loyalty intention (Delcourt 2016) [16]. Prior work suggests that experiencing negative emotions, and anger in particular, focuses one's attention on the source of those emotions (Simon 1967) [17]. Reducing consumers' attention to other aspects of the environment (e.g., product attributes, other employees, store atmospherics). Consumers who witness the uncivilized behavior of their employees can lead consumers to infer that other employees in the business are behaving similarly. The whole enterprise has similar problems, and the future contact with this enterprise will be negative (Porath et al. 2010) [18]. If the consumer witnesses the complaining behavior of the employee, it may also cause negative emotions. Based on heuristic clues, it infers that other employees of the company have similar behaviors. The entire enterprise has similar problems, and later is even more reluctant to contact the enterprise.

\section{Service encounter evaluation model}

In service settings, customer satisfaction is often influenced by the quality of the interpersonal interaction between the customer and the contact employee. Bitner (1994) proposes the model of service encounter evaluation incorporates consumer attributions within the satisfaction paradigm. [19] Attributions are what people perceive to be the causes behind their own behavior, the behaviors of others, or the events they observe (Weiner 2014) [20]. Weiner (1985) conclude that people will spontaneously form the thinking of attribution, especially when perceiving unexpected and negative events [21]. The conclusion that most causes can be classified on three dimensions: Locus (who is responsible?), control (Did the responsible party have control over the cause?), and stability (Is the cause likely to recue?) (Weiner 2000) [22]. The nature of the attributions made 
has been shown to influence both affective and behavioral responses (Folkes, 1984) [23]. That is, consumers witness to front-line service employees complaining, will spontaneously form the attribution of complaints, and then influence the evaluation of the enterprise. What is the responsibility of consumers when they see, or hear, employees complaining? The enterprise, employee itself or employee complaints? If the consumer blames the employee's complaints on the enterprise, it could lead to more negative consumer evaluations of the enterprise. When consumers see or hear employee complaining, if consumers feel that the employee's complaint is that the enterprise can control but have no control, it will lead to more negative evaluation of the enterprise. And when consumers see or hear employee complaining, If consumers feel that their employees complain that their behavior is stable and likely to happen again, they will have more negative comments on the business than the consumers feel the employee complains is accidental.

\section{Research Design}

\section{Research technique}

Since there's no scholars study the impact of complaining behavior between front-line service employees on consumers, So this article uses the critical incident technique to carry on the exploratory research, to analyze how consumers perceive complaints among front-line service employees.

\section{Critical incident technique}

The critical incident technique consists of a set of procedures for collecting direct observations of human behavior in such a way as to facilitate their potential usefulness in solving practical problems and developing broad psychological principles (Bitner 1999) [19]. As a qualitative research method, the critical incident technique is more informative than the objective figure, and it is more advantageous for the content analysis to seek the deep reason of the critical incident (Gremler 2004) [24]. And CIT is applicable to any research on classification (Chell 1997) [25]. It also helps to provide a basis for subsequent empirical research.

\section{Research procedure \\ Questionnaire design}

The content of the questionnaire is divided into three parts, the first part is the subjective question, please recall the complaint behavior of the front-line service employees as consumers see and hear. We define critical incidents as the complaints of front-line service employees that respondents see or hear from the consumer's point of view. For the consumer to describe the process of the event in detail, we refer to Hoffman's (1995) research to require that critical incidents meet the following four criteria: First, the front-line employees complained about the behavior occurred in the workplace. Second, from the consumer perspective perception of front-line employees complaining behavior. Three, an independent experience. Four, there are enough details to be visualized [26].

The second part is objective problem, including responsibility attribution 
measurement, the measurement items from Katja Gelbrich (2010) [27] and Liu et al. (2012) [28]. Inference measurement the measurement items from Porath (2010) [18], enterprise evaluation and brand evaluation Zeithaml (1996) [29] and Micael Dahlen (2006) [30]. Objective type of problem are used seven scale (1 $=$ completely disagree, 2 = disagree, $3=$ a little disagree, $4=$ uncertain, $5=$ a little agree, $6=$ agree, 7 = completely agree). The third part is the basic situation of the individual. Questionnaire in Appendix.

\section{Data collection}

Consumption as a universal behavior, student groups also have a lot of experience, so we use convenient sampling, students and postgraduates of Jinan University as a sample to participate in the questionnaire survey. The final collection of 300 samples, which said that they had a consumer perspective to witness the experience of front-line employee complained that the sample of 207, that is $69 \%$ of consumers believed to have witnessed front-line service employee complaints, including women 137 people, accounting for $66.2 \%$. According to critical incident technique standards, this study removed 33 incidents which does not belong to the consumer perspective perception of front-line employees complaining behavior. As described as "At the restaurant, I heard two couriers complaining." not belong to the workplace," The woman in charge of the order is swearing at another employee with a bad attitude." not Enough detail. Finally, 174 effective critical incidents are available. Consumer scenarios focus on restaurants, supermarkets and shopping malls.

\section{Data analysis results}

In this study, the complaint behavior of front-line service employees seen or heard by consumers is divided into 3 categories and 9 types. Consumer witness the type of complaint and the impact of the first-line service employees as shown in Table 1. As can be seen from Table 1, the first type of complaint is $41.95 \%$, of which the complaints about remuneration are the highest is $18.97 \%$. Consumers are more responsible for this type of complaint as employees and consider the salary and the ability of employees related. Unreasonable system, overtime, working environment complain responsibility belong to higher level of enterprise, more considered to be an enterprise impersonal.

The second type of complaint is the largest proportion, which is $45.4 \%$, where the highest intensity of complaint is $23.56 \%$, followed by complaining about the consumer is $19.54 \%$. Consumers witness front-line service employees complaining about other consumers, will form two different views, the first is to think that consumer error, such as "employees complaining about not queuing consumers," will be responsible for the consumer, Second, consumers have no errors, such as "employees complain that consumers do not buy, to rub air conditioning," will be responsible for the employee, and create a strong sense of anger, will think that employees may also complain about themselves. The third type of complaints accounted for the smallest proportion of $12.64 \%$, employees complained about leadership, consumer responsibility for the company's higher level, employees complained about colleagues, responsibility for the employee level 
Table 1. Consumer witness of the first-line waiter complaint type and impact.

\begin{tabular}{|c|c|c|c|c|c|}
\hline Type & Frequency & Percentage & $\begin{array}{l}\text { Responsibility } \\
\text { Attribution Enterprise }\end{array}$ & $\begin{array}{c}\text { Responsibility } \\
\text { Attribution } \\
\text { Employee }\end{array}$ & $\begin{array}{l}\text { Responsibility } \\
\text { Attribution } \\
\text { complaining } \\
\text { object }\end{array}$ \\
\hline \multicolumn{6}{|c|}{ 1) Complaints triggered by corporate employee responsibilities } \\
\hline a) Low pay & 33 & $18.97 \%$ & 4.85 & 5.15 & - \\
\hline b) Unreasonable system & 23 & $13.22 \%$ & 5.30 & 5.04 & -— \\
\hline c) Overtime & 15 & $8.62 \%$ & 5.13 & 4.53 & - \\
\hline d) Working environment & 2 & $1.15 \%$ & 5.50 & 3.00 & - \\
\hline Total & 73 & $41.95 \%$ & & & \\
\hline \multicolumn{6}{|c|}{ 2) Complaints triggered by corporate consumer responsibility } \\
\hline a) High intensity of work & 41 & $23.56 \%$ & 5.12 & 5.13 & - \\
\hline b) High work attitude required & 4 & $2.30 \%$ & 4.32 & 6.00 & - \\
\hline c) Complaining about the consumer & 34 & $19.54 \%$ & 4.71 & 4.91 & 5.32 \\
\hline Total & 79 & $45.40 \%$ & & & \\
\hline \multicolumn{6}{|l|}{ 3) Employee Personal Relationships } \\
\hline a) Leadership relationship & 13 & $7.47 \%$ & 5.54 & 5.23 & 5.77 \\
\hline b) Colleague Relations & 9 & $5.17 \%$ & 5.22 & 5.44 & 4.67 \\
\hline Total & 22 & $12.64 \%$ & & & \\
\hline Totals & 174 & & & & \\
\hline
\end{tabular}

$\begin{array}{lccccc}\text { Type } & \begin{array}{c}\text { Infer that other } \\ \text { employees have } \\ \text { similar complaints }\end{array} & \begin{array}{c}\text { Infer that the entire } \\ \text { enterprise has a } \\ \text { similar employee } \\ \text { complaint behavior }\end{array} & \begin{array}{c}\text { Infer that future } \\ \text { contacts with the } \\ \text { company will still } \\ \text { encounter similar } \\ \text { employee complaints }\end{array} & \begin{array}{c}\text { Enterprise } \\ \text { evaluation }\end{array} & \begin{array}{c}\text { Brand } \\ \text { evaluation }\end{array} \\ & & \end{array}$

\section{1) Complaints triggered by corporate employee responsibilities}

$\begin{array}{llllll}\text { a) Low pay } & 5.91 & 5.09 & 5.58 & 4.67 & 4.42 \\ \text { b) Unreasonable system } & 5.83 & 5.35 & 5.57 & 3.78 & 4.00 \\ \text { c) Overtime } & 5.67 & 4.87 & 5.40 & 4.27 & 4.20 \\ \text { d) Working environment } & 6.00 & 5.50 & 5.50 & 3.00 & 4.00\end{array}$

2) Complaints triggered by corporate consumer responsibility

\begin{tabular}{|c|c|c|c|c|c|}
\hline a) High intensity of work & 5.73 & 5.46 & 5.46 & 4.02 & 3.93 \\
\hline b) High work attitude required & 5.75 & 5.50 & 4.75 & 5.00 & 5.50 \\
\hline c) Complaining about the consumer & 5.29 & 4.94 & 5.21 & 5.15 & 5.29 \\
\hline \multicolumn{6}{|l|}{ 3) Employee Personal Relationships } \\
\hline a) Leadership relationship & 5.77 & 4.62 & 5.23 & 3.08 & 2.92 \\
\hline b) Colleague Relations & 5.67 & 5.44 & 5.33 & 3.44 & 4.22 \\
\hline
\end{tabular}

Note: The responsibility attribution, the inference behavior, the enterprise evaluation, the brand evaluation all uses the 7 scale ( 1 completely different meaning 7 completely agrees). 
higher, consumers will be more of the leadership behavior as an enterprise behavior. It should be noted that consumers witness the complaints of a single frontline service employee, infer that other employees have similar complaints, and that there are similar employee complaints across the enterprise, and that future contact with the company will meet similar employee complaints.

\section{Conclusion and Suggestion}

The research found that consumers can witness the complaint behaviors among the front-line service employees. Even if the maximum responsibility is not the enterprise, it is considered that the company has a responsibility. It will also lead consumers to make more profound negative inferences, affecting the inference of other employees of the company, the entire company, and future contacts with the company. When consumers witnessed that front-line service employees complained about leadership, work environment, system, and work intensity, the level of corporate evaluation and brand evaluation was low. Probably because these actions are problems that companies can control but not control relative to other complaints, consumers are more likely to think that they are inhumane. Managers should pay enough attention to grievances among front-line service employees, especially complaints caused by uncontrollable problems that companies can control, identify specific incidents, conduct upgrades, and strengthen communication with first-line service employees. These help improve corporate evaluation. Therefore, this paper gives the following suggestions to enterprise managers.

First, effectively identify the impact factors of employee complaints. The most of the types of consumer witness complaints are the intensity of the work, and follow is the salary treatment. Second, improve the enterprise staff complaints management mechanism, change employee complaints to employee advices within the organization, such as setting up employee suggestion boxes and communicating with employees regularly. Third, try to use intelligent management software to simplify the workload of the front-line service employees.

The research conclusion only discusses the type of complaint behavior between front-line service employees and its influence on consumers, but the internal mechanism of the influence of different complaint types on consumers remains to be tested.

\section{Funding}

This paper is supported by the humanities and social sciences fund of the Ministry of Education (16YJA630076).

\section{References}

[1] Gao, Y. (2014) Causes of Knowledge-Based Employees' Complains at Workplace: An Exploratory Study. East China Economic Management.

[2] Godard, J. and Frege, C.M. (2014) Worker Perceptions of Representation and 
Rights in Germany and the USA. European Journal of Industrial Relations, 20, 73-89. https://doi.org/10.1177/0959680113516846

[3] Mowbray, P.K., Wilkinson, A. and Tse, H.H.M. (2015) An Integrative Review of Employee Voice: Identifying a Common Conceptualization and Research Agenda. International Journal of Management Reviews, 17, 382-400. https://doi.org/10.1111/ijmr.12045

[4] Watty-Benjamin, W. and Udechukwu, I. (2014) The Relationship Between HRM Practices and Turnover Intentions: A Study of Government and Employee Organizational Citizenship Behavior in the Virgin Islands. Public Personnel Management, 43, 58-82. https://doi.org/10.1177/0091026013508546

[5] Surprenant, C.F. and Solomon, M.R. (1987) Predictability and Personalization in the Service Encounter. Journal of Marketing, 51, 86-96.

https://doi.org/10.2307/1251131

[6] Tavassoli, N.T., Sorescu, A., Chandy, R., et al. (2014) Employee-Based Brand Equity: Why Firms with Strong Brands Pay Their Executives Less. Journal of Marketing Research, 51, 676-690. https://doi.org/10.1509/jmr.13.0435

[7] Wentzel, D. (2009) The Effect of Employee Behavior on Brand Personality Impressions and Brand Attitudes. Journal of the Academy of Marketing Science, 37, 359-374. https://doi.org/10.1007/s11747-009-0140-6

[8] Asha, C.S. and Jyothi, P. (2013) Internal Branding: A Determining Element of Organizational Citizenship Behaviour. Journal of Contemporary Management Research.

[9] Shivakumar, R. (2014) How to Tell Which Decisions are Strategic. California Management Review, 56, 78-97. https://doi.org/10.1525/cmr.2014.56.3.78

[10] Mcwilliams, A. and Siegel, D. (2001) Corporate Social Responsibility: A Theory of the Firm Perspective. Academy of Management Review, 26, 117-127.

[11] Zhang, Z.G., Chuan-Peng, Y.U. and Lin, C.P. (2012) Empirical Study on the Corporate Social Responsibility Influencing Employees' Job Satisfaction-The Organizational Affective Commitment as the Mediated Variable. Economic Management Journal.

[12] Hartline, M.D. and Ferrell, O.C. (1996) The Management of Customer-Contact Service Employees: An Empirical Investigation. Journal of Marketing, 60, 52-70. https://doi.org/10.2307/1251901

[13] Bitner, M.J. (1992) Servicescapes: The Impact of Physical Surroundings on Customers and Employees. Journal of Marketing, 56, 57-71. https://doi.org/10.2307/1252042

[14] Qiu, W. and Bai, C.H. (2012) Service Brand Internalization Process and Its Empirical Research Based on the Perspective of Employees. Nankai Business Review.

[15] Hennigthurau, T., Groth, M., Paul, M., et al. (2006) Are All Smiles Created Equal? How Emotional Contagion and Emotional Labor Affect Service Relationships. Journal of Marketing, 70, 58-73. https://doi.org/10.1509/jmkg.70.3.58

[16] Delcourt, C.C., Gremler, D., Riel, A.C.R.V., et al. (2016) Employee Emotional Competence: Construct Conceptualization and Validation of a Customer-Based Measure. Journal of Service Research, 30, 2186-2194. https://doi.org/10.1177/1094670515590776

[17] Simon, H. (1967) Motivational and Emotional Controls of Cognition. Psychological Review, 74, 29-39. https://doi.org/10.1037/h0024127

[18] Porath, C., Macinnis, D. and Folkes, V. (2010) Witnessing Incivility among Em- 
ployees: Effects on Consumer Anger and Negative Inferences about Companies. Journal of Consumer Research, 37, 292-303. https://doi.org/10.1086/651565

[19] Bitner, M.J., Booms, B.H. and Mohr, L.A. (1994) Critical Service Encounters: The Employee's Viewpoint. Journal of Marketing, 58, 95-106.

https://doi.org/10.2307/1251919

[20] Weiner, B. (2014) The Attribution Approach to Emotion and Motivation: History, Hypotheses, Home Runs, Headaches/Heartaches. Emotion Review, 6, 353-361. https://doi.org/10.1177/1754073914534502

[21] Weiner, B. (1985) An Attributional Theory of Achievement Motivation and Emotion. Psychological Review, 92, 548-573. https://doi.org/10.1037/0033-295X.92.4.548

[22] Weiner, B. (2000) Attributional Thoughts about Consumer Behavior. Journal of Consumer Research, 27, 382-387. https://doi.org/10.1086/317592

[23] Folkes, V.S. (1984) Consumer Reactions to Product Failure: An Attributional Approach. Journal of Consumer Research, 10, 398-409. https://doi.org/10.1086/208978

[24] Gremler, D.D. (2004) The Critical Incident Technique in Service Research. Journal of Service Research, 51, 65-89. https://doi.org/10.1177/1094670504266138

[25] Chell, E. and Pittaway, L. (1997) A Study of Entrepreneurship in the Restaurant and Café Industry: Exploratory Work using the Critical Incident Technique as a Methodology. International Organization, 41, 639-665.

[26] Hoffman, K.D., Kelley, S.W. and Rotalsky, H.M. (1995) Retrospective: Tracking Service Failures and Employee Recovery Efforts. Journal of Services Marketing, 9, 49-61. https://doi.org/10.1108/08876049510086017

[27] Gelbrich, K. (2010) Anger, Frustration, and Helplessness after Service Failure: Coping Strategies and Effective Informational Support. Journal of the Academy of Marketing Science, 38, 567-585. https://doi.org/10.1007/s11747-009-0169-6

[28] Liu, R.P., Cao, Z.P., Fan, G.W., et al. (2014) Service Recovery for Service Failure Caused by the Other Customer Misbehavior.

[29] Zeithaml, V.A. (1996) The Behavioral Consequences of Service Quality. Journal of Marketing, 60, 31-46. https://doi.org/10.2307/1251929

[30] Dahlen, M. and Lange, F. (2006) A Disaster Is Contagious: How a Brand in Crisis Affects Other Brands. Journal of Advertising Research, 46, 388-397.

https://doi.org/10.2501/S0021849906060417 


\section{Appendix}

\section{Part 1}

1) Please recall that in the last year, have you ever been the experience that as consumer in the consumer occasions (such as shopping malls, restaurants, etc.) see or hear the first-line employee complained?

2) Please describe this experience in as much detail as possible. Including

a) When did the incident occur?

b) In what consumption situation did the incident take place?

c) What did the employee say or do at that time? What did you do?

d) Your thoughts and feelings.

e) Will it affect your perception of the brand? What is the impact? Why?

\section{Part 2}

\begin{tabular}{|c|c|c|}
\hline Variable & Items & literature reference \\
\hline \multirow{4}{*}{ Brand evaluation } & I think the company brand is a good brand & \multirow{4}{*}{$\begin{array}{l}\text { Katja Gelbrich (2010) } \\
\text { Liu et al. (2012). }\end{array}$} \\
\hline & I trust the company's brand & \\
\hline & If someone asked me to recommend, & \\
\hline & I would recommend the company brand & \\
\hline \multirow{4}{*}{$\begin{array}{l}\text { Enterprise } \\
\text { evaluation }\end{array}$} & I think this is a trustworthy enterprise & \multirow{4}{*}{$\begin{array}{c}\text { Zeithaml (1996) } \\
\text { Micael Dahlen (2006) }\end{array}$} \\
\hline & I think this is a responsible enterprise & \\
\hline & & \\
\hline & I'd like to patronize the enterprise next time & \\
\hline \multirow{3}{*}{$\begin{array}{c}\text { Inference } \\
\text { measurement }\end{array}$} & I infer that other employees have similar complaints & \multirow{3}{*}{ Porath (2010) } \\
\hline & $\begin{array}{l}\text { I infer that the entire enterprise has a similar employee } \\
\text { complaint behavior }\end{array}$ & \\
\hline & $\begin{array}{l}\text { I infer that future contacts with the company will still } \\
\text { encounter similar employee complaints }\end{array}$ & \\
\hline
\end{tabular}

